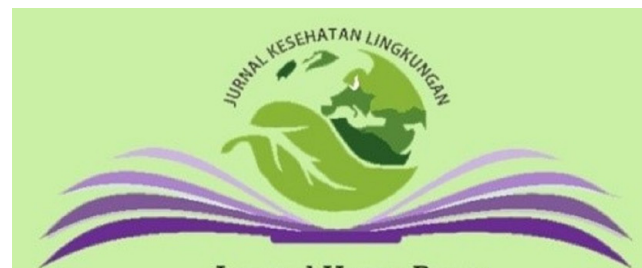

Journal Home Page:

https://e-journal.unair.ac.id/JKL

\section{Jurnal Kesehatan Lingkungan}

Vol. 14 No. 1

DOI: $10.20473 /$ jkl.vl4il.2022.11-20

ISSN: 1829 - 7285

E-ISSN: 2040 - 881X

\title{
TROPICAL CLIMATE LESS AFFECTS COVID19 TRANSMISSION THAN POPULATION DENSITY: PERSPECTIVE OF INDONESIA
}

\section{Anwar Rovik ${ }^{* *}$, Anggi Pratama², Ayu Rahayu ${ }^{1}$}

${ }^{1}$ Center of Tropical Medicine, Faculty of Medicine, Public Health and Nursing, Universitas Gadjah Mada, Yogyakarta 55281, Indonesia

${ }^{2}$ Master Student at School of Life Sciences and

Technology, Institute of Technology Bandung, West

Java 40132, Indonesia

\section{Corresponding Author:}

*) rovic.anwar@gmail.com

\section{Article Info}

Submitted

In reviewed

Accepted

20 August 2021

11 November 2021

Available Online

Keywords : Covid19 pandemic, Indonesia,

Population density, Tropical climate.

Published by Fakultas Kesehatan Masyarakat Universitas Airlangga

\begin{abstract}
Introduction: Indonesia is ranked the $4^{\text {th }}$ most populous country in the world. Since Covid19 is highly transmissible from human to human, Indonesia might suffer a long period of the Covid19 pandemic than other less-populous countries. This study aimed to find the correlations of tropical climate, population density and confounding factors with Covid19 progression in Indonesia from March to August 2020. Methods: The climatological data, population density, laboratory testing, and the confirmed Covid19 cases were statistically analyzed. The correlations between each data were performed with Pearson's Correlation Coefficient using a Statistical Package for the Social Sciences. The values of statistical significance were considered at $95 \%$ and $99 \%$ confidence intervals. Results and Discussion: Indonesia recorded more than 1,315 confirmed Covid19 cases in almost all provinces (30 out of 34) during the dry season (March to August 2020). During the early pandemic, DKI Jakarta and East Java have been the epicenters of the pandemic in Indonesia. Humidity and precipitation have a weak negative correlation, while the temperatures have a weak positive correlation. Population density and laboratory testing have a strong positive and significant correlation with the cumulative confirmed Covid19 cases. Conclusion: Our study indicates that tropical climate less affects the cumulative Covid19 case in Indonesia than population density and laboratory testing capacity.
\end{abstract}

\section{INTRODUCTION}

On March 11 $11^{\text {th }}, 2020$, the World Health Organization (WHO) announced the occurrence of the novel coronavirus disease-2019 (Covid19 as a global pandemic. As of November $4^{\text {th }}, 2020$, the Severe Acute Respiratory Syndrome Coronavirus 2 (SARS-CoV-2) has spread to 219 countries and affected over $46,840,783$ individuals globally with $1,204,028$ recorded deaths (1). The range of Covid19 transmission is much broader than the SARS-CoV infection that caused the epidemic of SARS in 2003. When SARS-CoV-2 was at its peak in China from December 2019 to February 2020, ASEAN countries revealed no occurrences of infection. As of December 15, 2021, Indonesia has recorded 4,259,439 confirmed cases with 143,960 deaths and 4,110,574 recovered cases (2).

The Covid19 disease is a pathogenic respiratory SARS-CoV-2 viral infection. SARS-CoV-2 has some genetic resemblance to other coronaviruses found in farm or domestic animals. The virus genome sequence research also reveals that SARS-CoV-2 is highly adapted to human cell surface receptors, allowing it to penetrate human cells and infect people quickly. It is highly transmissible from human to human, typically transmitted via coughing, sneezing, and touching the contaminated surfaces (3-4) This ever-present feature is observed commonly in respiratory viral diseases, such as influenza (5-6) and other human coronaviruses (7).

The Covid19 virus is both a biological and a social phenomenon. It spread only when specific social and environmental conditions acted on the source of infection, the mechanism of transmission, and the population's vulnerability (8). Coronavirus transmission can be influenced directly or indirectly by many factors such as environmental conditions (humidities, temperatures, precipitation, and wind speed), population density, and the availability of health facilities (6,9-10). Pathogen survival can be influenced by environmental conditions during host changes. Changes can occur within brief periods (e.g., droplet-transmitted infections can become aerosol sources of transmission). Environmental factors influence host vulnerability to infection as well as vector population dynamics (10). Environmental factors can influence the host immune responses and make cells more susceptible to infection in terms of host susceptibility (11). 
The current study indicates that climate significantly influences the cumulative confirmed Covid19 cases at certain locations. Humidity and temperature are associated with Covid19 infection and death rates. Temperature and humidity were found to be inversely related to Covid 19 new cases and mortality daily in the $\mathrm{Wu}$ et al. analyses in 166 countries (12). Every $1^{\circ} \mathrm{C}$ increase in temperature reduces daily new cases by $3.08 \%$ and daily new deaths by $1.19 \%$; every $1 \%$ change in humidity reduces daily new cases of Covid 19 by $0.85 \%$ and daily new deaths by $0.51 \%$. More research has revealed that seasonal cyclicity may be a common feature of acute infectious diseases such as respiratory viral diseases. Each acute infectious disease has a cyclical window of occurrence that varies according to its geographic location (10). Some case studies in Beijing, Hong Kong, Taiyuan, and Guangzhou revealed that SARS epidemics were linked to temperature fluctuations (8). In Italy, the relationship between daily confirmed cases and humidity, velocity, temperature using multivariate analysis (11).

Indonesia is ranked the $4^{\text {th }}$ most populous country in the world. Since Covid19 is highly transmissible from human to human, Indonesia might suffer a long period of the Covid19 pandemic than other less-populous countries. The population density, which is a proxy for social distance, is considered more important than meteorological variables. The population impact on transmissions, such as disease invasion and persistence thresholds, has frequently been studied as a technique for differentiating pathogen transmissibility in geographic areas. The population impact on transmissions, such as the threshold of pathogen invasion and persistence, has frequently been investigated as a method of distinguishing pathogen transmissibility in a geographic area. Moreover, the occurrence of the next wave of Covid19 pandemic should be anticipated. Since numerous factors may affect the pandemic, this study aimed to find the correlations of tropical climate, population density, and confounding factors with Covid19 progression in Indonesia from March to August 2020. This study's findings may help the Government to predict the condition of the Covid19 pandemic over the coming years in Indonesia.

\section{METHODS}

The daily data of confirmed Covid19 cases (March $1^{\text {st }}$ to August $31^{\text {st }}, 2020$; early pandemic in Indonesia) were collected from Indonesian government authorities by Indonesia Task Force for Covid19. The data were recorded from 34 provinces in Indonesia (1-2). The climatological parameters (temperatures, rainfall precipitation, and humidity) were sourced from the
Meteorological, Climatological, and Geophysical Agency of Indonesia. The climatological data were recorded daily from 163 different stations. Daily confirmed Covid 19 cases and climatological data were calculated proportionally as monthly data from March to August 2020.

Population density and laboratory testing capacities: The Province population density was retrieved from Statistics of Indonesia (2). The data were collected during the first trimester of 2020. Meanwhile, the daily testing capacity of reference laboratories was presented by the Ministry of Health $(\mathrm{MoH})$ of Indonesia. The data analysis was performed by using a Microsoft Excel spreadsheet. The averages of climatological data (temperatures, humidity, and rainfall precipitation) were calculated from March to August 2020 in every 33 provinces with 163 different stations in Indonesia. The data from Kalimantan Utara Province (as a new province declared in 2012) were excluded due to the lack of a climate station. The analysis results were presented by using diagrams and distribution maps. Tropical climate, population density, laboratory test, and cumulative confirmed Covid19 data were analyzed statistically. The correlations between each data were performed with Pearson's Correlation Coefficient using a Statistical Package for the Social Sciences (SPSS-IBM Corp., Armonk, NY). The values of statistical significance were considered at $95 \%$ and $99 \%$ confidence intervals $(\mathrm{Cl})$.

\section{RESULTS}

Indonesia recorded more than 1,315 confirmed Covid19 cases in almost all provinces (30 out of 34) during the dry season (March to August 2020). The first recorded Covid19 case was on March $2^{\text {nd }}, 2020$ (2). The cases were increasing rapidly in the next month that covered all provinces. As of August 31 st, 2020 , the five highest cumulative Covid19 cases were recorded from DKI Jakarta, East Java, South Sulawesi, West Java, and Central Java Province, respectively (Figure 1).In 2020, Statistics of Indonesia reported the current population number in Indonesia. West Java Province is the most populous area with $46,092,205$ people, followed by East Java, Central Java, North Sumatera, and DKI Jakarta Province with more than 11 million inhabitants. Meanwhile, DKI Jakarta Province is ranked the densest area in 2020 with $16,718.01$ people $/ \mathrm{km}^{2}$, followed by West Java, DI Yogyakarta, Banten, and Central Java Province with more than 1,100 people $/ \mathrm{km}^{2}$. Figure 2 shows that during the early pandemic, DKI Jakarta has been the epicenter of the pandemic since it recorded the most cumulative Covid19 and mortality cases (2). East Java Province, the $6^{\text {th }}$ densest area, recorded the 
second-highest cumulative Covid19 cases in which Surabaya City is the main contributor. Therefore, East
Java has been the second epicenter of the pandemic in Indonesia (2).

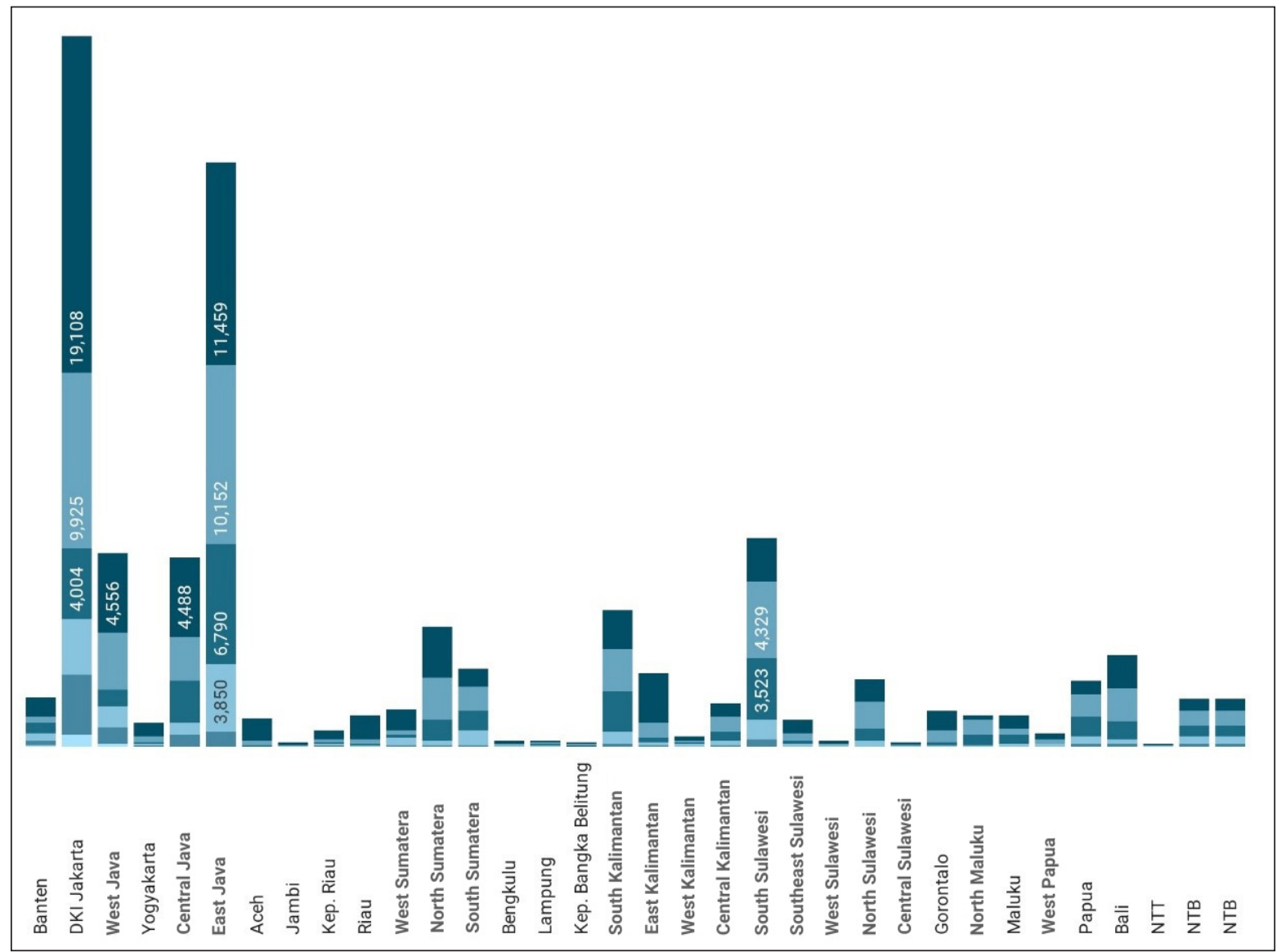

Figure 1. The cumulative count of confirmed Covid19 cases in Indonesia from March to August 2020 (2)

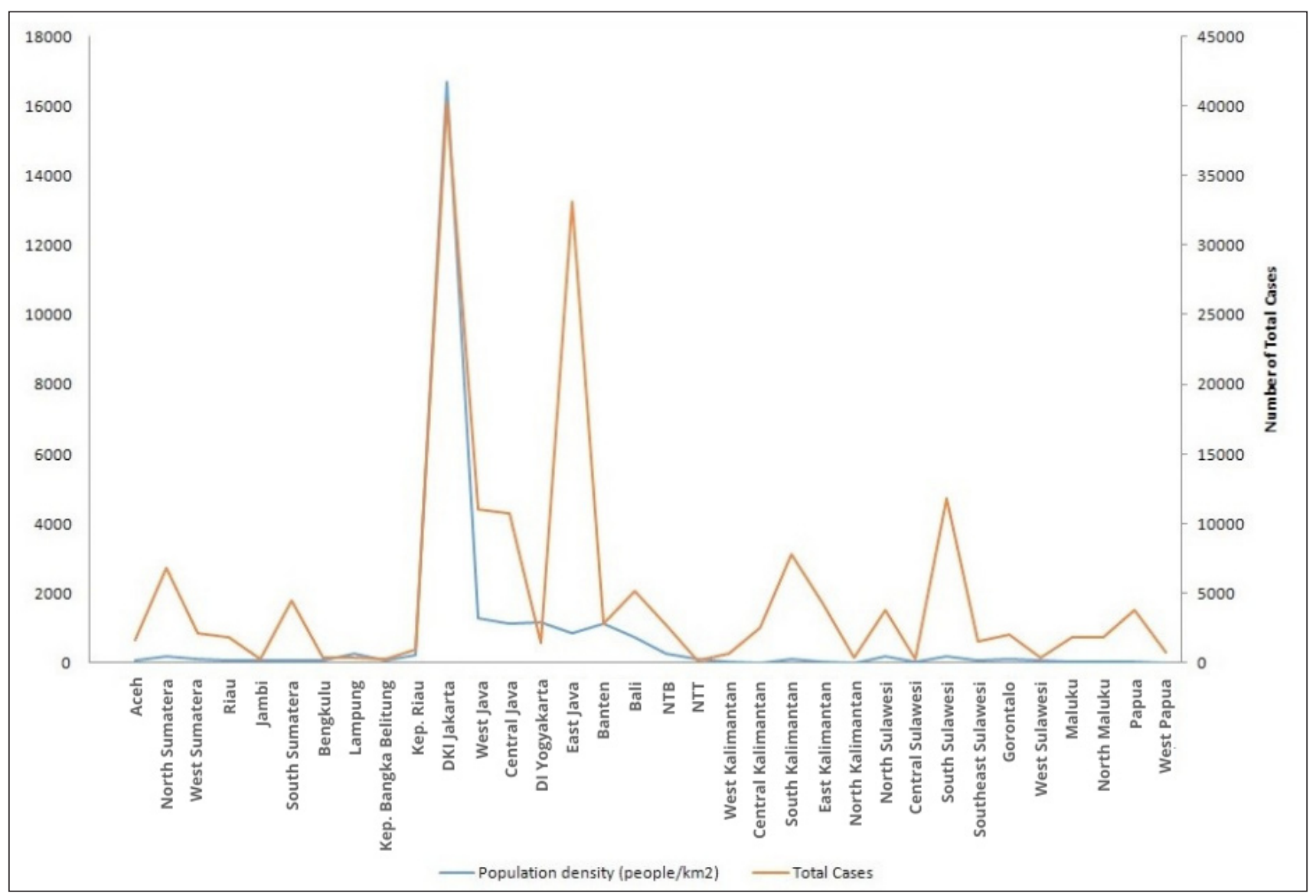

Figure 2. The Correlations Between Cumulative Covid19 Cases and Population Density by the Province in Indonesia. 
As of November 2020, Indonesia has 542 diagnostic laboratories for Covid19 screening across provinces (Figure 3a). A total of 88 laboratories are located in East Java, both governmental and nongovernmental laboratories, with some Biosafety Level-2 (BSL-2) mobile-type laboratories. DKI Jakarta, West
Java, Central Java, and North Sumatera Province have a lot of diagnostic laboratories for Covid19. The number of diagnostic centers is increasing to deal with the population number and Covid19 cases. Basically, the more laboratories, the more testing capacity that is available for each day (Figure 3b).

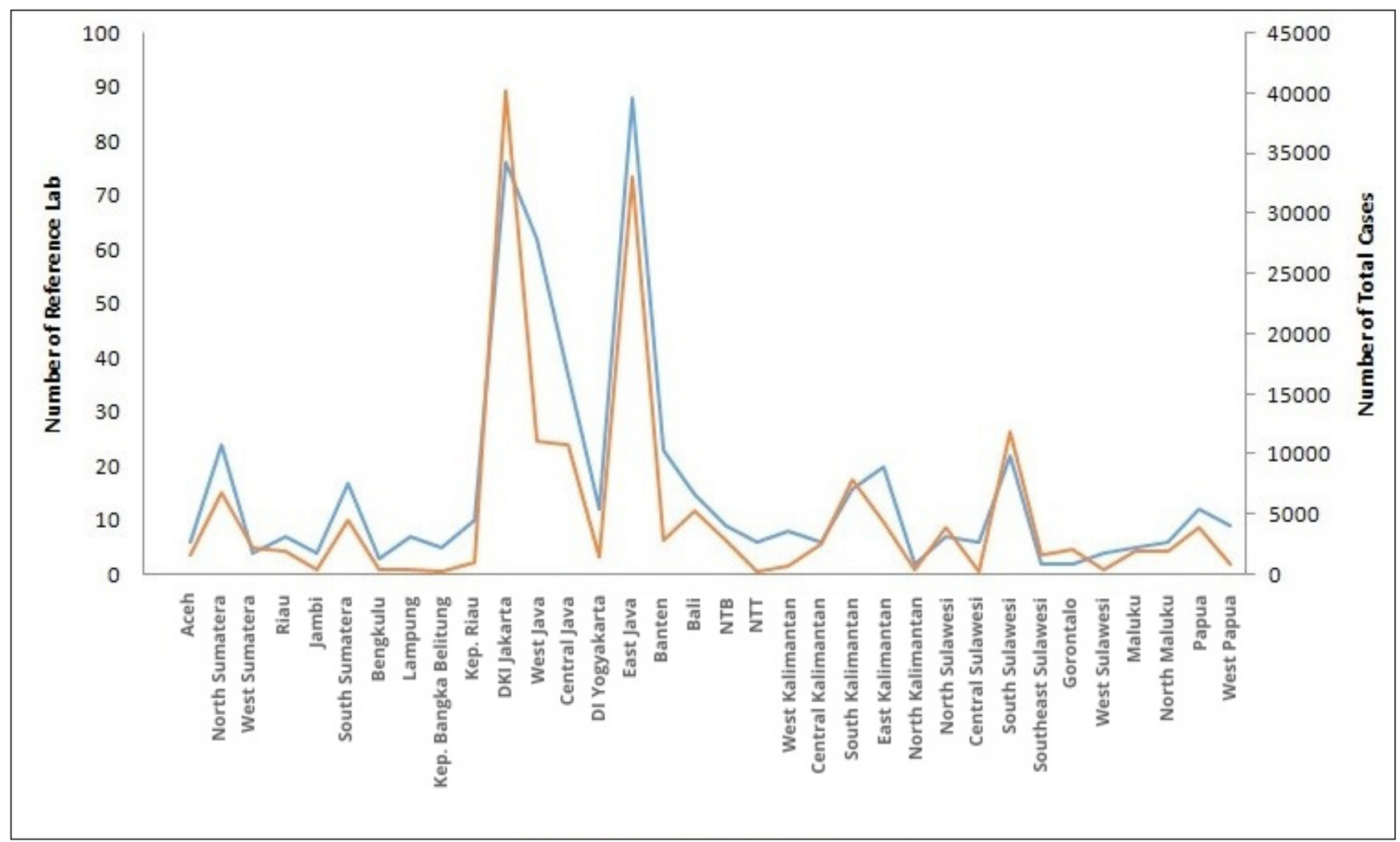

(a)

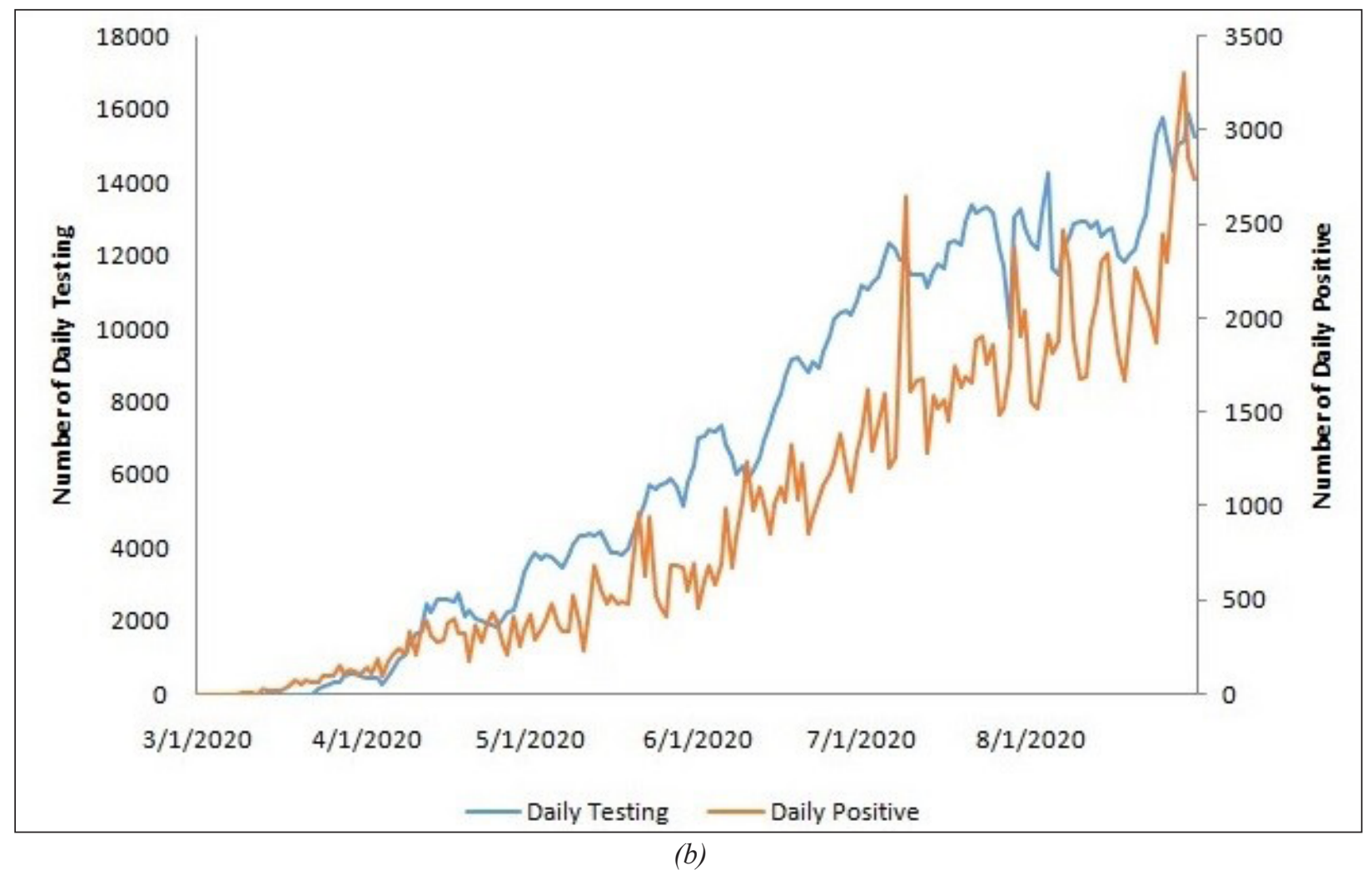

Figure 3. The Correlations Between Cumulative Covid19 Cases and the Number of Reference Laboratories (a) and Daily Testing (b) 
We monitored the range of different climatological data from March to August 2020. The visualization showed average monthly temperatures across Indonesia ranged from 25.99 to $29.02^{\circ} \mathrm{C}$. The highest average temperatures were recorded in DKI Jakarta in May at $29.48^{\circ} \mathrm{C}$. Meanwhile, the lowest average temperatures were recorded in Jambi in July at $25.45^{\circ} \mathrm{C}$ (Figure $4 \mathrm{a}$ ). The environmental-relative humidity ranged from 76.43 to $87.35 \%$. This condition might be related to the humidity range of Indonesia as a tropical country. The highest average humidities were recorded from Kepulauan Bangka Belitung in April at $88.80 \%$. The lowest average humidity was presented at Nusa Tenggara Timur in July of $73.39 \%$ (Figure $4 b$ ). The rainfall precipitation was distributed differently across Indonesia ranging from 2.91 to $18.81 \mathrm{~mm}^{3}$ per month. The highest rainfall precipitation was obtained from Papua during March 2020 at $26.27 \mathrm{~mm}^{3}$ per month. The lowest rainfall precipitation was presented at Nusa Tenggara Timur during August 2020 (Figure 4c).

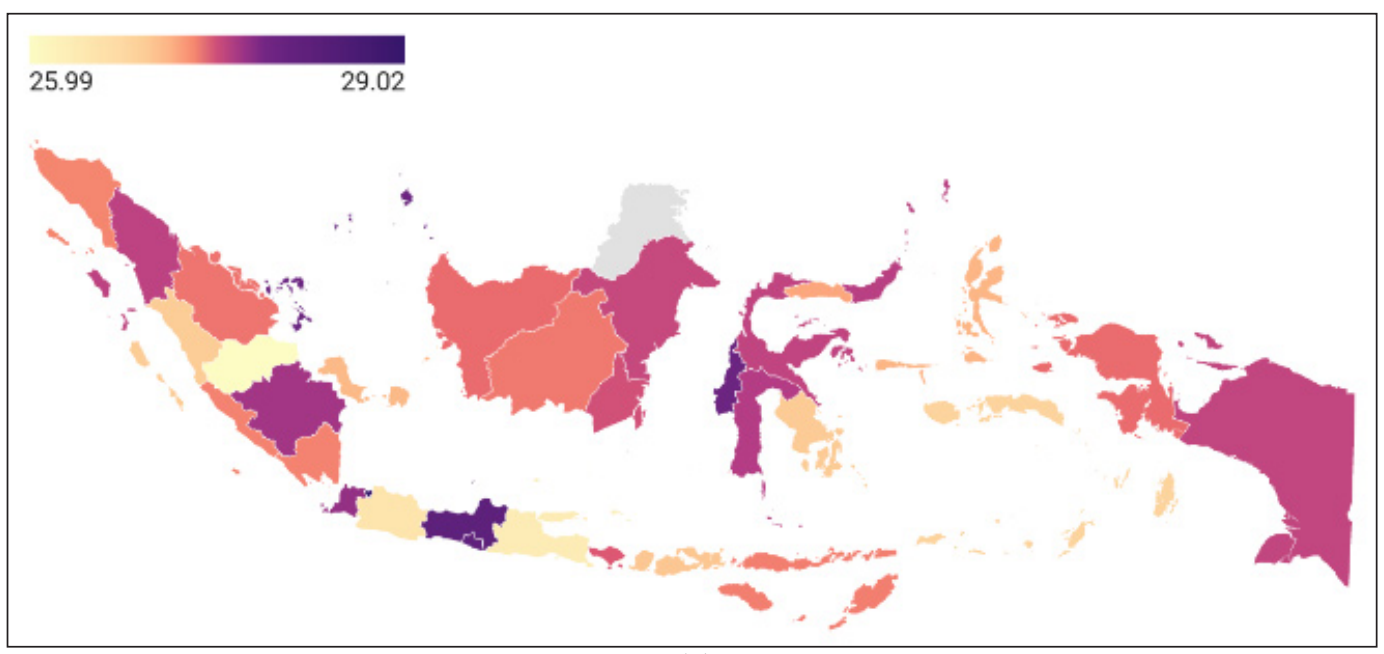

(a)

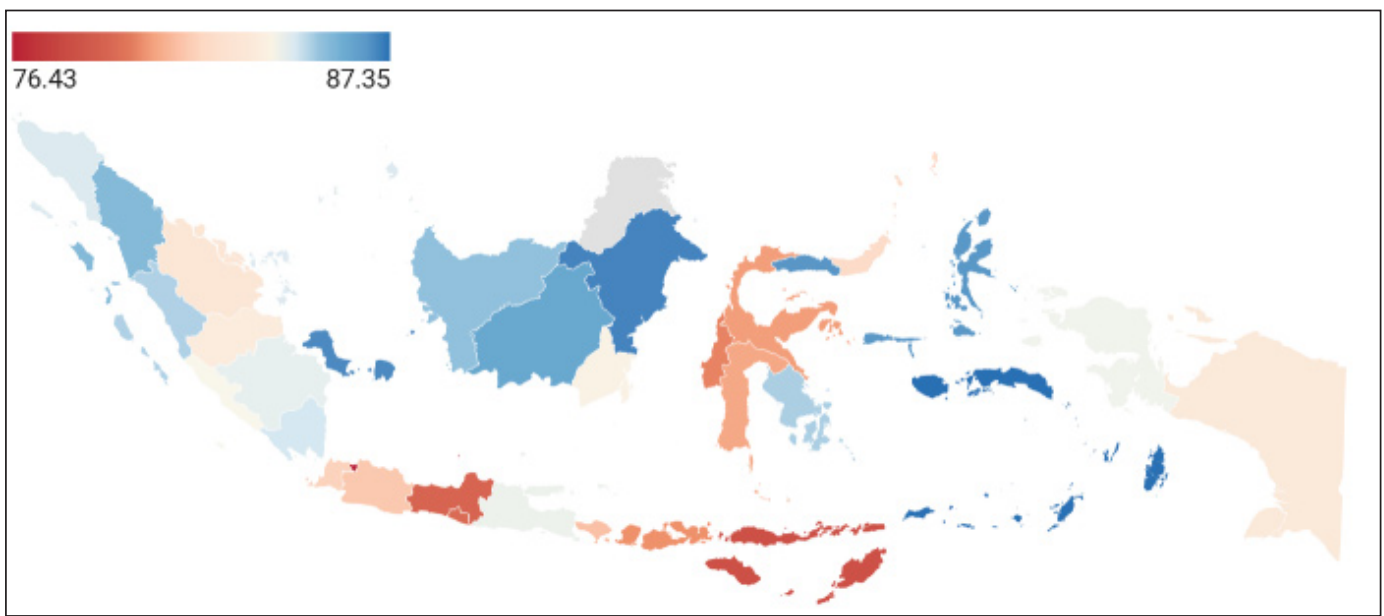

(b)

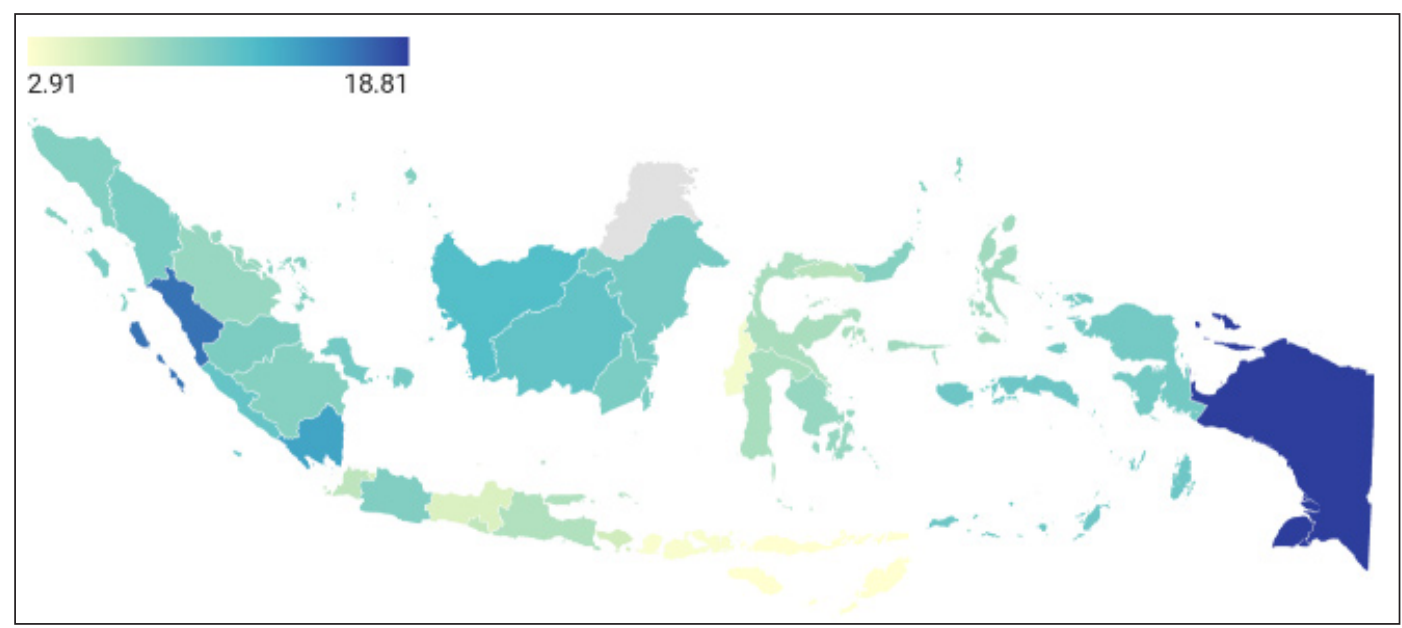

(c)

Figure 4. The Distribution and Range of Average Temperatures (a), Humidities (b), and Rainfall Precipitation (c) in Indonesia from March to August 2020 
The correlation analysis was performed with Pearson's Correlation Coefficient using an SPSS program. The values of statistical significance were considered at $95 \%$ and $99 \% \mathrm{Cl}$. The classification of the correlation levels was as follows: at $0.00-0.19$ as very weak, 0.20-0.39 as weak, 0.40-0.59 as moderate, 0.600.79 as a strong, and $0.80-1.00$ as a robust correlation. Therefore, the temperature parameter presented a weak positive correlation with the cumulative confirmed Covid19 cases. Humidity and precipitation have a weak negative correlation.
Table 1. Correlations Between the Cumulative Confirmed Covid19 Cases in Indonesia and Its Cofounding Factors

\begin{tabular}{lc}
\hline Climatological Parameters & $\begin{array}{c}\text { Pearson's Correlation } \\
\text { Coefficient }\end{array}$ \\
\hline Average Temperatures $\left({ }^{\circ} \mathrm{C}\right)$ & 0.227 \\
Average Humidities $(\%)$ & $-0.366^{*}$ \\
Average Rainfall precipitation $\left(\mathrm{mm}^{3}\right)$ & -0.214 \\
Population density $\left(\right.$ per $\left.\mathrm{km}^{2}\right)$ & $0.754^{* *}$ \\
Reference laboratories & $0.919^{* *}$
\end{tabular}

Note:

* significant at a 95\% confidence interval

** significant at a 99\% confidence interval

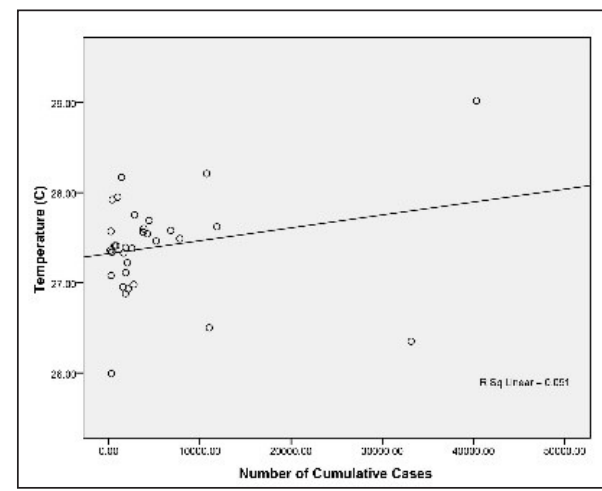

(a)

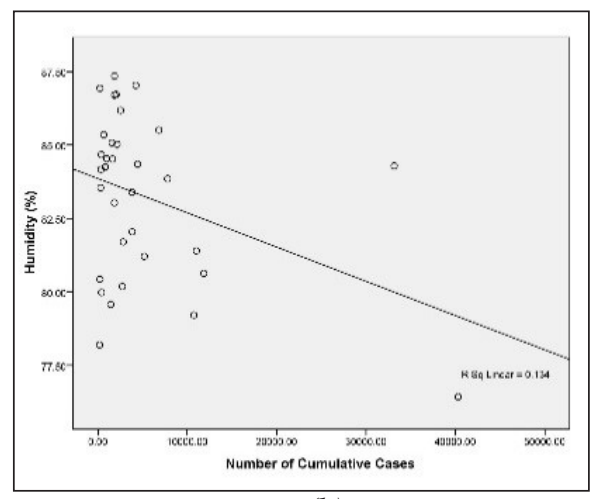

(b)

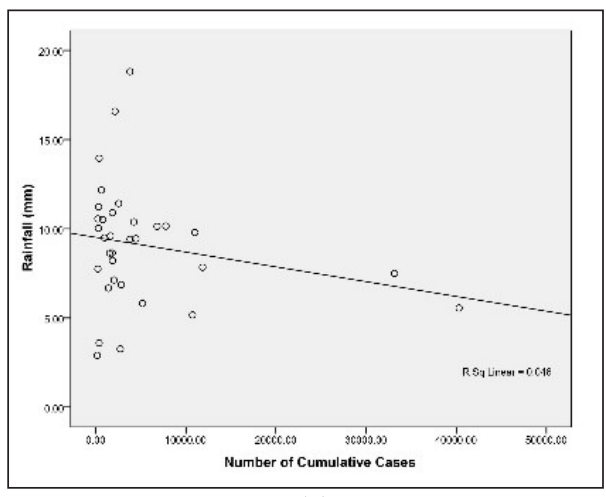

(c)

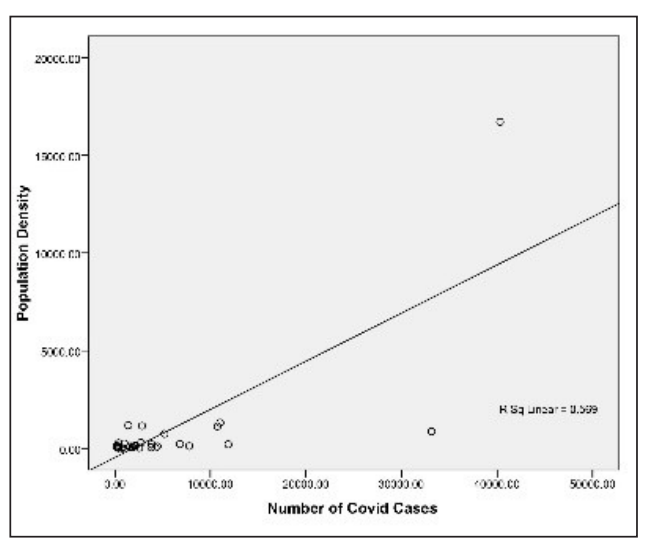

(d)

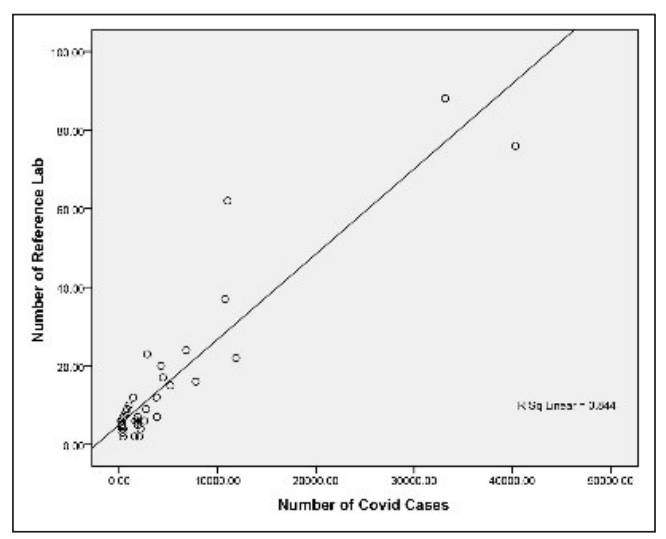

(e)

Figure 5. The Correlations Between the Cumulative Confirmed Covid19 Cases and Climatological Parameters

(a) temperature; (b) humidity; (c) rainfall in Indonesia from March to August 2020; (d) population density; and (e) the number of reference or diagnostic laboratories.

\section{DISCUSSION}

On March 31, 2020, by issuing the Presidential Decree No. 11 regarding the Determination of the Corona Virus Disease 2019 (Covid19) Public Health Emergency, Indonesia declared the Covid19 pandemic a national public health emergency. Besides, the Government announced both social and public health measurements in preventing, mitigating, and handling the Covid19 pandemic in Indonesia. During the early pandemic, the National Institute of Health Research and Development referred to a central laboratory for Covid19 testing. However, the centralized diagnostic location makes the Covid19 testing time time-consuming and delays an effectual response. Since rapid diagnosis is essential for the $3 \mathrm{~T}$ program (tracing, testing, and treatment), the Ministry of Health $(\mathrm{MoH})$ encouraged the provincial diagnostic laboratory centers to elevate the testing capacity and reporting time. The Circular Letter No. HK.02.01/Menkes/234/2020 regarding Guidelines for Examination of the SARSCoV-2 Time-Polymerase Chain Reaction (RT-PCR) for Laboratories in Hospitals and Other Laboratories Conducting Corona Virus Disease 2019 (Covid19) Examinations provided a guideline on SARS-CoV-2 testing for non-government laboratories, including universities. This policy was important in dealing with the current situation. Although, it leads to the ongoing and incoming challenges of integrating the daily data recording and reporting. 
Figure 3 demonstrated the significance of expanding the number of diagnostic laboratories. The number of Covid19 diagnostic laboratories strongly correlates with the daily testing capacity. The laboratory capacity resulted in various factors, such as the availability of adequate materials and tools, rapid RNA extraction, skills, and provided training. On July $29^{\text {th }}$, the daily testing had reached over 30,000 suspicious samples, exceeding the WHO's testing capacity target of 1 in 1,000 residents per week (2). Figure 5 e showed the strong correlation of testing capacity with daily cumulative Covid19 cases. The testing capacity is essential to support contact tracing, the management of the patient, and the overall pandemic. Therefore, the Indonesian Government should increase the daily testing capacity and number.

Since the SARS-CoV-2 virus is highly transmissible from human to human (12), it is assuming that Covid19 is transmitted rapidly in the populationdense area. In our present study, the population density was correlated strongly with the cumulative confirmed Covid19 cases (Figure 5d). It indicates that high population density can promote a pandemic or epidemic. It also confirms the importance of social and/or physical distancing for at least 1 meter as a public health measurement in preventing the Covid19 transmission.

The analysis result of the cumulative count of Covid19 cases showed that DKI Jakarta, Sulawesi Selatan, East Java, West Java, and Central Java Province were the five most affected provinces from March to August 2020 (Figure 1). In 2019, those provinces were recorded as the twelve most densely populated provinces (1). Figure 2 showed that the Province of DKI Jakarta is the epicenter of the Covid19 pandemic in Indonesia. During the last five years, DKI Jakarta province is ranked the densest area, with a population density of $16,718.01$ people $/ \mathrm{km}^{2}$ in 2020 (1). Another independent study reported that population density affects the infection and mortality rate of Covid19 cases in populous or metropolitan areas, for example, DKI Jakarta and Padang City in Indonesia (13-15).

Pandemics are more likely to hit earlier in dense provinces. High mobility is one of the factors to contribute to the cases of Covid19 in Jakarta. As Indonesia's capital city, Jakarta is one of the most popular economic destinations for job seekers from all over the country; this situation allows Covid19 to spread quickly, as Jakarta province is well connected to the rest of the world. Cities that have high densities usually have public facilities that support the activities of many people such as transportations terminals, stadiums, supermarkets, train stations, etc. Because of the extended intimate contact between hosts, it may represent a high risk of disease transmission. The disease's invasion into a local population is a two-stage process that begins with movement between local populations and ends with an increase in the number of infected individuals. After the initial seeding, secondary dissemination is fueled by the effective transmission power of disease among local contacts.

Environmental studies may also predict the progression of the Covid19 pandemic in Indonesia. Climate factors have received the most attention as seasonal drivers. Climate has a constant correlation with the pathogen, host, and environmental factors of infectious diseases (15). Epidemiological surveillance also supports the correlations of environmental conditions with the occurrence of the Covid19 pandemic. Located in the equatorial area, Indonesia's climatic condition is strongly influenced by monsoon winds which create hot and humid conditions.

The temperature is an important factor that presents a different impact on the living environment and public health. During 2004, the daily environmental temperatures in Indonesia ranged from $22-33^{\circ} \mathrm{C}$ (1). This present study showed that the increase in average temperatures positively correlates with the cumulative count of confirmed Covid19 cases but not significantly (Figure 5a, Table 1). The rising temperature also affects human mobilization. With higher temperatures, people tend to stay at home. In a modeling analysis, Wei et al. found that when the temperature was below $10^{\circ} \mathrm{C}$, a higher average temperature had a considerable negative influence on Covid19 risk, whereas the effect was minor when the temperature was above $10^{\circ} \mathrm{C}$ (16). During observation, the daily environmental temperatures in Indonesia range from 25.99 to $29.02^{\circ} \mathrm{C}$ (Figure 4a).

Previous studies presented a positive correlation between mean temperatures and cumulative Covid19 cases at a narrow range of variability and fluctuation of daily temperatures (17-18), including some Asian countries in tropical areas. For example, studied in China and United States discovered that Covid19 transmission speed was proportional to temperature. The Covid19 transmission rate is projected to increase by an average of 1.8 days as the temperature rises to $20^{\circ} \mathrm{C}$ (19). Other research, on the other hand, found a negative relationship between environmental temperature and the accumulation of Covid19 cases in subtropical nations (18,20-21) and death rates globally (22). When the temperature rises by $1^{\circ} \mathrm{C}$, confirmed cases drop by 4.9 percent in 122 Chinese cities, according to a similar 
study in China (23). The results confirm that temperature influences human health differences between countries and regions.

Due to the pathogenicity, virulence duplication, infectivity, and survival of the SARS virus, data suggest that a temperature range of $16-28^{\circ} \mathrm{C}$ may be the ideal temperature for SARS prevalence (8). This indicates that the Indonesian range temperature is suitable for the life of the SARS virus. There is also the possibility of SARSCoV-2 stability in the air. As a result, in confined spaces where there is a risk of infection, it is recommended to use an airflow change, virus filters, negative pressure air pollution, and closed suctioning. In general, the virus will begin to be inactivated at high temperatures. One invitro study found the stability of SARS-CoV-2 at $4^{\circ} \mathrm{C}$ and its sensitivity to heat (24). Outside of those appropriate ranges, virus longevity is reduced but still adequate for transmission, as the adaptive immunity to previously discovered coronaviruses is absent (25).

The average 76.43 to $87.35 \%$ humidity has a weak negative association and is correlated significantly with the increase of the cumulative confirmed Covid19 cases in Indonesia (Figure 5b, Table 1). It indicates that the cumulative confirmed Covid19 cases increased with decreasing humidities in Indonesia. Previous studies presented evidence of a negative correlation of relative humidities with the transmission rate of Covid19 both in tropical $(4,26)$ and subtropical countries $(18,27)$. Bu suggested that Covid19 is highly transmissible at 50 $80 \%$ humidity (28). In low environmental humidities, infectious droplets form much smaller size particles $(14,29)$ which provide more chances of infectious viral particles inhalation (30-31).

High humidity, which is linked with low temperatures, is also a significant determinant in the influenza virus's transmissibility. The previous study has discovered that influenza viruses are more stable at low temperatures. Droplets harboring viruses from the respiratory tract also have a longer shelf life in cold temperatures. It may also apply to the mechanism of SARS-CoV-2 transmission. Breathing dry weather may cause nasal mucosal moisture loss, resulting in epithelial injury and/or impaired mucus secretion, making the host more vulnerable to the respiratory infectious agent. Prolonged dry air exposure prevents viral development in the upper respiratory tract. At the virus mechanism level, the stability of virions in an aerosol has been recorded with varying relative humidity $(\mathrm{RH})$, with viral stability being greatest at low $\mathrm{RH}(32)$.
The average rainfall precipitation has a weak negative association but is not correlated significantly with the increase of the cumulative confirmed Covid19 cases during the early pandemic (Figure $5 c$, Table 1 ). It indicates a lower rate of Covid19 transmission during higher precipitation. In higher rainfall precipitation, people tend to stay at home, thereby reducing the virus transmission. Bu suggested a favorable range of rainfall precipitation for virus survival is $30 \mathrm{~mm} /$ month or less (29). Studies found a low influence of rainfall precipitation on the transmission rate of Covid19 both in tropical and subtropical countries $(19-20,33)$. High rainfall precipitation decreases the evaporation of infectious droplets which increases the opportunity to spread viruses (34). Several studies reported that no significant correlation between rainfall and Covid19 (27), while other studies, however, have discovered a significant negative link between rainfall and Covid19 cases in the United States, with routine cases increasing between 1.27 and 1.74 inches of rainfall and reducing above 1.77 inches of rainfall (35). Study in in Oslo, Norway discovered a substantial inverse relationship between daily precipitation amounts measured at 7 a.m (36).

In summary, our study presented the correlations of Covid19 progression in Indonesia and its impacting factors: tropical climate, population density, and laboratory testing capacity. Humidity and precipitation have a weak negative correlation, even if the temperatures have a weak positive correlation. Population density and laboratory testing have a strong positive and significant correlation with the cumulative confirmed Covid19 cases. It should be noted that correlation is a relationship between two items in which one aspect changes in relation to the other. Our study did not investigate the causal relationship, which suggests that one occurrence can trigger another. According to our findings, Covid19 transmission tends to decrease as ambient temperatures, humidity, and rainfall precipitation decrease. This circumstance, however, does not imply that the decrease in virus infectiousness is due to a drop in temperatures, humidity, or rainfall. In future research, the possibility of a causal association between the two variables will need to be further investigated.

\section{ACKNOWLEDGEMENTS}

The authors thank the Indonesia Task Force for Covid19, the Meteorological, Climatological, Geophysical Agency of Indonesia, and the related agencies for providing the data. The authors are also grateful to the medical personnel for dealing with the Covid19 pandemic in Indonesia. 


\section{CONCLUSIONS}

Our study indicates that tropical climate less affects the cumulative Covid19 cases in Indonesia than population density and laboratory capacity. There is no doubt that population density and social behavior are notable factors of virus transmission. Several other factors, such as low community immunity and a lack of discipline in applying health measures, will result in epidemics comparable to those seen in subtropical regions. Our findings and understanding of the association between Covid19 progressions with their impacting factors may also contribute to the decision-making process to fight and control the current pandemic. The study's research evidence has policy implications for limiting the incidence of Covid19. Staying at home and taking precautionary actions such as avoiding handshakes, wearing a face mask, and regularly washing hands with soap and running water (and using a 70\% alcohol-based sanitizer) will slow the spread of Covid19.

\section{REFERENCES}

1. Worldometer. Covid19 Coronavirus Pandemic. United States: Worldometer. https://www. worldometers.info/coronavirus/

2. Indonesian Task Force for Covid19. Information and Data of Covid19. Jakarta: Indonesian Task Force for Covid19; 2020. https://www.covid19.go.id/

3. Heininger U. Severe Acute Respiratory Syndrome Coronavirus 2 Vaccines: Setting Expectations Appropriately. Pediatr Infect Dis J. 2020;39(7):E123-124. https://doi.org/10.1097/ inf.0000000000002741

4. Pani SK, Lin NH, Ravindrababu S. Association of Covid19 Pandemic with Meteorological Parameters over Singapore. Sci Total Environ. 2020;740(140112):1-10. https://doi.org/10.1016/j. scitotenv.2020.140112

5. Chattopadhyay I, Kiciman E, Elliott JW, Shaman JL, RzhetskyA. Conjunction of Factors Triggering Waves of Seasonal Influenza. Elife. 2018;7(e30756):1-44. https://doi.org/10.7554/eLife.30756

6. Puspa KD, Pangesti KNA, Setiawaty V. Effects of Climate Change on The Distribution of Influenza Virus in Indonesia in 2012-2013. Heal Sci J Indones. 2015;5(2):78-82. https://doi.org/10.22435/hsji.v5i2 Dec.3594.78-82

7. Killerby ME, Biggs HM, Haynes A, Dahl RM, Mustaquim D, Gerber SI, et al. Human Coronavirus Circulation in The United States 2014-2017. J Clin Virol. 2018;101(1):52-56. http://dx.doi. org/10.1016/j.jcv.2018.01.019

8. Dalziel BD, Kissler S, Gog JR, Viboud C, Bjørnstad ON, Metcalf CJE, et al. Urbanization and Humidity Shape The Intensity of Influenza Epidemics in U.S. Cities. Science. 2018;362(6410):75-79. https://doi. org/10.1126/science.aat6030
9. Martinez ME. The Calendar of Epidemics: Seasonal Cycles Oof Infectious Diseases. PLoS Pathog. 2018;14(11):1-15. https://doi.org/10.1371/journal. ppat. 1007327

10. Foxman EF, Storer JA, Fitzgerald ME, Wasik BR, Hou L, Zhao H, et al. Temperature-Dependent Innate Defense Against The Common Cold Virus Limits Viral Replication at Warm Temperature in Mouse Airway Cells. Proc Natl Acad Sci. 2015;112(3):827832. https://doi.org/10.1073/pnas.1411030112

11. Wu Y, Jing W, Liu J, Ma Q, Yuan J, Wang Y, et al. Effects of Temperature and Humidity on The Daily New Cases and New Deaths of Covid19 in 166 Countries. SciTotalEnviron.2020;729(139051):1-7. https://doi.org/10.1016/j.scitotenv.2020.139051

12. Pirouz B, Sha S, Pirouz B, Sha S, Piro P. Development of an Assessment Method for Investigating the Impact of Climate and Urban Parameters in Confirmed Cases of Covid19: A New Challenge in Sustainable Development. Int J Environ Res Public Health. 2020;17(8):2801. http:// dx.doi.org/10.3390/ijerph17082801

13. Prather BKA, Wang CC, Schooley RT. Reducing transmission of SARS-CoV-2. Science. 2020;368(6498):1422-1424. https://doi. org/10.1126/science.abc6197

14. Sari PN, Alfian AR, Firdani F. Correlation of Ambient Temperature with Increasing of Covid19 Cases in a Tropical City. J Kesehat Lingkung. 2021;13(3):186192. http://dx.doi.org/10.20473/jkl.v13i3.2021.186192

15. Bhadra A, Mukherjee A, Sarkar K. Impact of Population Density on Covid19 Infected and mortality rate in India. Model Earth Syst Environ. 2021;7(1):623-629. https://doi.org/10.1007/ s40808-020-00984-7

16. Tosepu R, Gunawan J, Effendy DS, Ahmad LOAI, Lestari $\mathrm{H}$, Bahar $\mathrm{H}$, et al. Correlation Between Weather and Covid19 Pandemic in Jakarta, Indonesia. Sci Total Environ. 2020;725(138136):1-4. https://doi.org/10.1016/j.scitotenv.2020.138436

17. Wei J Te, Liu YX, Zhu YC, Qian J, Ye RZ, Li CY, et al. Impacts of Transportation and Meteorological Factors on The Transmission of Covid19. Int J Hyg Environ Health. 2020;230(113610):1-7. https://doi. org/10.1016/j.ijheh.2020.113610

18. Ma Y, Zhao Y, Liu J, He X, Wang B, Fu S, et al. Effects of Temperature Variation and Humidity on The Death of Covid19 in Wuhan, China. Sci Total Environ. 2020;724(138226):1-7. https://doi. org/10.1016/j.scitotenv.2020.138226

19. Wang J, Tang K, Feng K, Lu W. High Temperature and High Humidity Reduce the Transmission of Covid19. BMJ Open. 2020;11(2):e043863. https:// doi.org/10.2139/ssrn.3551767

20. Ujiie M, Tsuzuki S, Ohmagari N. Effect of Temperature on the Infectivity of Covid19. Int J Infect Dis. 2020;95(1):301-303. https://doi.org/10.1016/j. iiid.2020.04.068

21. Wu F, Zhao S, Yu B, Chen YM, Wang W, Song ZG, et al. A New Coronavirus Associated with 
Human Respiratory Disease in China. Nature. 2020;579(7798):265-269. https://doi.org/10.1038/ s41586-020-2008-3

22. Iqbal MM, Abid I, Hussain S, Shahzad N, Waqas MS, Iqbal MJ. The Effects of Regional Climatic Condition on The Spread of Covid19 at Global Scale. Sci Total Environ. 2020;739(140101):1-9. https://doi.org/10.1016/j.scitotenv.2020.140101

23. Xie J, Zhu Y. Association Between Ambient Temperature and Covid19 Infection in 122 Cities from China. Sci Total Environ. 2020;724(138201):1-5. https://doi.org/10.1016/j.scitotenv.2020.138201

24. Chin AWH, Chu JTS, Perera MRA, Hui KPY, Yen $\mathrm{H}-\mathrm{L}$, Chan MCW, et al. Stability of SARS-CoV-2 in Different Environmental Conditions. The Lancet Microbe. 2020;1(1):e10. http://dx.doi.org/10.1016/ S2666-5247(20)30003-3

25. McClymont H, HuW. Weather Variability and Covid 19 Transmission: A Review Of Recent Research. Int $J$ Environ Res Public Health. 2021;18(2):1-19. https://doi.org/10.3390/ijerph18020396

26. Suhaimi NF, Jalaludin J, Latif MT. Demystifying a Possible Relationship Between Covid19, Air Quality and Meteorological Factors: Evidence from Kuala Lumpur, Malaysia. Aerosol Air Qual Res. 2020;20(7):1520-1529. https://doi.org/10.4209/ aaqr.2020.05.0218

27. Yao Y, Pan J, Liu Z, Meng X, Wang W, Kan H, et al. No Association of Covid19 Transmission With Temperature or UV Radiation in Chinese Cities. Eur Respir J. 2020;55(5):7-9. https://doi. org/10.1183/13993003.00517-2020

28. Bu J, Peng D-D, Xiao H, Yue Q, Han Y, Lin Y, et al. Analysis of Meteorological Conditions and Prediction of Epidemic Trend of 2019-nCoV Infection in 2020. Preprints medRxiv. 2020;1(1). https://doi.org/10.11 01/2020.02.13.20022715

29. Feng Y, Marchal T, Sperry T, Yi H. Influence of Wind and Relative Humidity on The Social Distancing Effectiveness to Prevent Covid19 Airborne Transmission: A Numerical Study. J Aerosol Sci. 2020;147(105585):1-19. https://doi.org/10.1016/j. jaerosci.2020.105585

30. Ahlawat A, Wiedensohler A, Mishra SK. An Overview on The Role of Relative Humidity in Airborne Transmission Of SARS-CoV-2 in Indoor Environments. Aerosol Air Qual Res. 2020;20(9):1856-1861. https://doi.org/10.4209/ aaqr.2020.06.0302

31. Somsen GA, van Rijn C, Kooij S, Bem RA, Bonn D. Small Droplet Aerosols In Poorly Ventilated Spaces and SARS-CoV-2 Transmission. Lancet Respir Med. 2020;8(7):658-659. http://dx.doi.org/10.1016/ S2213-2600(20)30245-9

32. Ng CS, Chong KL, Yang R, Li M, Verzicco R, Lohse D. Growth of Respiratory Droplets in Cold and Humid Air. Phys Rev Fluids. 2021;6(5):1-15. https://doi.org/10.1103/PhysRevFluids.6.054303

33. Méndez-Arriaga F. The Temperature and Regional Climate Effects on Communitarian Covid19 Contagion in Mexico Throughout Phase 1. Sci Total Environ. 2020;735(139560):1-23. https://doi. org/10.1016/j.scitotenv.2020.139560

34. Lu C Wei, Liu X Fen, Jia Z Fang. 2019-nCoV Transmission Through The Ocular Surface Must Not Be Ignored. Lancet. 2020;395(10224):e39. http://dx.doi.org/10.1016/S0140-6736(20)30313-5

35. Chien LC, Chen LW. Meteorological Impacts on the Incidence of Covid19 in The U.S. Stoch Environ Res Risk Assess. 2020;34(10):1675-1680. https:// doi.org/10.1007/s00477-020-01835-8

36. Menebo MM. Temperature and Precipitation Associate With Covid19 New Daily Cases: A Correlation Study Between Weather and Covid19 Pandemic in Oslo, Norway. Sci Total Environ. 2020;737(139659):1-5. https://doi.org/10.1016/j. scitotenv.2020.139659 